\title{
Climate-growth relationships of the dominant tree species from semi-arid savanna woodland in Ethiopia
}

\author{
Aster Gebrekirstos · Ralph Mitlöhner • \\ Demel Teketay $\cdot$ Martin Worbes
}

Received: 28 June 2006/Revised: 4 March 2008/Accepted: 10 March 2008/Published online: 15 April 2008

(C) The Author(s) 2008

\begin{abstract}
Long-term climate-growth relationships, were examined in tree rings of four co-occurring tree species from semi-arid Acacia savanna woodlands in Ethiopia. The main purpose of the study was to prove the presence of annual tree rings, evaluate the relationship between radial growth and climate parameters, and evaluate the association of El Niño and drought years in Ethiopia. The results showed that all species studied form distinct growth boundaries, though differences in distinctiveness were revealed among the species. Tree rings of the evergreen Balanites aegyptiaca were separated by vessels surrounding a thin parenchyma band and the growth boundary of the deciduous acacias was characterized by thin parenchyma bands. The mean annual diameter increment ranged from 3.6 to $5.0 \mathrm{~mm}$. Acacia senegal and Acacia seyal showed more enhanced growth than Acacia tortilis and B. aegyptiaca. High positive correlations were found between the tree-ring width chronologies and precipitation data, and all species showed similar response to external climate forcing, which supports the formation of one tree-ring per year. Strong declines in tree-ring width correlated remarkably
\end{abstract}

Communicated by S. Leavitt.

A. Gebrekirstos $(\bowtie) \cdot$ R. Mitlöhner

Institute of Silviculture, Sect. II: Tropical Silviculture,

Georg-August University of Göttingen, Büsgenweg 1,

37077 Göttingen, Germany

e-mail: agebrekirstos@yahoo.com; agebrek@gwdg.de

D. Teketay

Forest Stewardship Council, African Regional Office, P.O. Box UP 805, Kumasi, Ghana

M. Worbes

Institute of Agronomy in the Tropics, Georg-August University of Göttingen, Grisebachstrasse 6, 37077 Göttingen, Germany well with past El Niño Southern Oscillation (ENSO) events and drought/famine periods in Ethiopia. Spectral analysis of the master tree-ring chronology indicated occurrences of periodic drought events, which fall within the spectral peak equivalent to 2-8 years. Our results proved the strong linkage between tree-ring chronologies and climate, which sheds light on the potential of dendrochronological studies developing in Ethiopia. The outcome of this study has important implications for paleoclimatic reconstructions and in restoration of degraded lands.

Keywords Tree-ring width - Acacia species ·

Balanities aegyptiaca . Climate change .

Dendrochronology

\section{Introduction}

The open savanna woodlands in Ethiopia, which have been estimated to cover $30 \%$ of the total land area of the country (FAO 1981), have suffered from deforestation (Argaw et al. 1999; Gebrekirstos 2006). In this connection, there are many visible symptoms of the adverse effects on the livelihood of the local population today. Restoration of the degraded landscapes will play a vital role in facilitating sustainable development (Lemeneh et al. 2004) and is therefore highly desirable. Management of woodlands on a sustainable basis is a challenge for people living in many arid and semi-arid areas of the world. For the development of sustainable silvicultural systems, for instance, knowledge of the long-term diameter increment growth of tropical forest trees and their reaction to climate is essential (Worbes 1999). However, knowledge of growth rates of tropical trees in general is extremely poor (Worbes et al. 2003). Despite their practical importance, the growth rate 
of woodland species in arid and semi-arid conditions are even dismissed as being low in comparison with most forest types (Gourlay 1995) and less documented than the closed forest (Eshete and Ståhl 1999). Hence, this study will provide growth rate data for managing important open savanna trees.

Furthermore, the effects of deforestation and land degradation are compounded by recurrent droughts. Severe droughts are the principal climate-related disaster in Ethiopia and their impact, i.e., in the form of famine and human migration, has been felt for a long time. Drought periods in Ethiopia were related to El Niño Southern Oscillation (ENSO) (Tesfaye 1988; Bekele 1993). Hence, information on ENSO has been used to forecast drought after the catastrophic 1983-1984 event. By making use of such information, for example, the Ethiopian Government managed to reduce the consequences of severe drought on people due to the 1987/1988 ENSO (Bekele 1993). However, the absence of long-term meteorological information in various parts of the country has been one of the major problems hindering effective long-term weather forecasting (Tesfaye 1988). This problem calls for urgently identifying potential proxies that can provide information about past climatic events.

Since tree rings have long been acknowledged as indicators of annual climatic information, radial growth responses can indicate the reaction of trees to past periodic droughts (Orwig and Abrams 1997), an eco-physiological record of past climate and ecological conditions (Sass and Eckstein 1995) and ENSO events (Cook 1992). Hence, longterm series of tree-ring width chronologies could be used as a proxy to reconstruct past climatic events. For example, dendrochronology has been widely applied in paleoclimate studies in the temperate climates, where the strong climate seasonality induces annual ring formation (e.g., Schweingruber et al. 1990). However, it has been widely assumed that tropical trees do not form annual wood rings (Lang and Knight 1983; Lieberman et al. 1985; Whitmore 1998). Contrary to this assumption, many authors have succeeded in using tree-ring measurements on tropical trees to determine tree age, understand growth dynamics and support ecological and climate studies, e.g., in the Amazon (Vetter and Botosso 1989; Worbes et al. 1992; Schöngart et al. 2004), Africa (Gourlay 1995; Stahle et al. 1999; Eshete and Ståhl 1999; Worbes et al. 2003; Eshetu and February 2003; Fichtler et al. 2004, Schöngart et al. 2006, Therrell et al. 2006), Central America (Enquist and Leffler 2001) and Asia (Pumijumnong 1999). This was possible since many tropical areas have at least two months of arid conditions, which induce cambial dormancy and trigger formation of growth boundaries (Worbes 1995). Formation of two rings per year was reported in areas with two distinct dry seasons (Jacoby 1989; Wayant and Reid 1992; Gourlay 1995) and fewer rings than their age in moist conditions (Eshete and Ståhl 1999). Eshete and Ståhl (1999) who evaluated the growth periodicity of acacia in Ethiopia, demonstrated statistically significant precipitation-growth relationships for 12 years (1982-1994). According to Pilcher (1990), to gain reliable results with regard to climate growth relations, the overlap of cross-dated time series should reach a minimum of 40 years. Apart from the acacias, a recent dendrochronological study on Juniperus procera in a dry Afromontane forest (Couralet et al. 2005) indicated the dendrochronological potential of this species for reconstructing precipitation and studying forest growth and population dynamics in Ethiopia. Other dendrochronological pilot studies on Juniperus procera and Prunes Africana reported yearly river discharge reconstructed from tree-ring width (Wils and Eshetu 2007). In light of these early studies, our purpose is to demonstrate, on the basis of long time-series, that tree rings in tropical Africa can be used as a tool for dendroclimatic and dendroecological applied research.

Hence this study focused on the dominant trees growing in arid and semi-arid Ethiopia, namely: Acacia tortilis (Forssk.) Hayne, Acacia seyal Del, Acacia senegal (L.) Wild., and Balanites aegyptiaca (L.) Del. The specific objectives of the study were to: (a) prove the presence of annual tree rings and understand tree growth dynamics of four naturally co-occurring tree species; (b) evaluate longterm growth patterns and the relationship between radial growth and climate parameters; and (c) evaluate the association of ENSO and drought/famine years in Ethiopia with tree-ring pointer years.

\section{Materials and methods}

Study area and species

The study was undertaken in the Acacia woodland in Abernosa, which is located within the upper Rift Valley lakes sub-region about $170 \mathrm{~km}$ south of Addis Ababa, $7^{\circ} 51^{\prime} \mathrm{N}$, $38^{\circ} 42^{\prime} \mathrm{E}$ at an elevation of about 1,600 m. It is characterized by a distinct dry season, with no or erratic rain of less than $40 \mathrm{~mm}$ per month between October and February. The major and minor rainfall periods are from June to September and March to June, respectively, and the wettest month is July (142 mm). Average annual precipitation, measured at Adami Tulu Research Center Metrological Station about $5 \mathrm{~km}$ away from the study area, was $760 \mathrm{~mm}$ and ranges between 550 and $900 \mathrm{~mm}$ (Fig. 1). The mean annual temperature is $20.7^{\circ} \mathrm{C}$ and varies little from year to year. The underlying parent material of the study area is characterized by acidic lava, ash and pumice interbedded with lacustrine siltstone and sandstones (Makin et al. 1975). The soils are sandy loam with $\mathrm{pH}$ of 6.75 . 


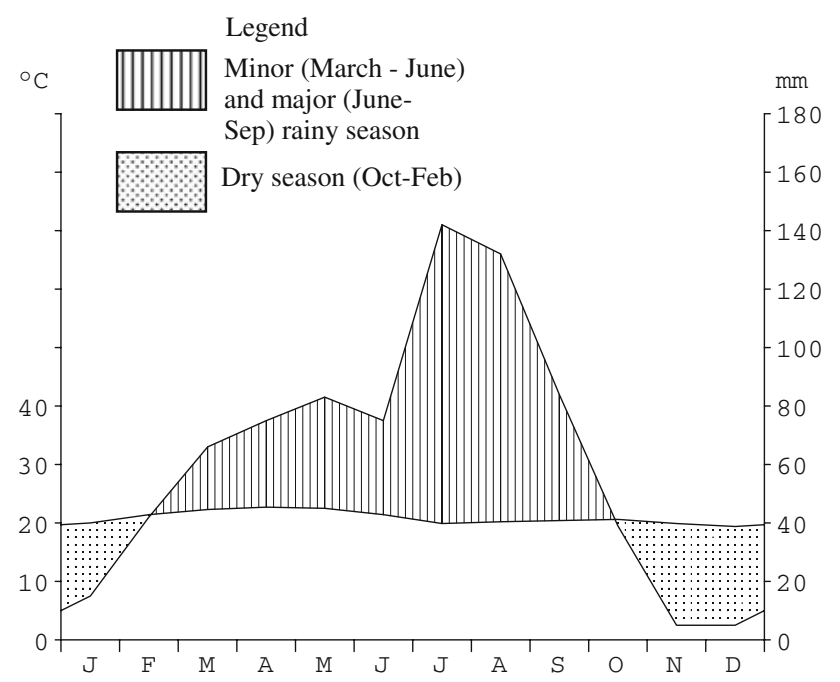

Fig. 1 Climatic diagram of the study site (in Abernosa) drawn according to Walter (1973). Rainfall (mm) and temperature $\left({ }^{\circ} \mathrm{C}\right)$ data (1980-2002) were obtained from Adamitulu Research Station, which is situated at about $5 \mathrm{~km}$ from Abernosa

The area is classified as a semi-arid ecoclimatic vegetation zone (Makin et al. 1975), and is a major part of the country's Acacia woodland and savannah region (Argaw et al. 1999). Large areas of the woodlands have been deforested and converted to arable and grazing lands. However, there was a cattle ranch protected from open access to grazing, tree cutting and settlement inside the boundary as a reference site of relatively undisturbed vegetation. The density of the trees was comparatively higher with a relatively closed canopy compared to the surrounding communal lands with an open access to grazing and cultivation. The communal and cultivated lands were part of the ranch until 1994. The most dominant tree species in the study area are A. tortilis, A. seyal, A. senegal and B. aegyptiaca (Gebrekirstos et al. 2006).
Hence, these species were analyzed for this study. The acacias are drought deciduous and are members of Fabaceae family, while the evergreen $B$. aegyptiaca belongs to Balanitaceae (Table 1). All the species are economically important, found all over Africa in arid, semi-arid and subhumid savannah. The ecology, morphological description, and use of the study species are described elsewhere (Azene Bekele et al.1993; Hedberg and Edwards 1989) as is their leaf shedding behavior and adaptation to water stress (Gebrekirstos et al. 2006).

\section{Tree-ring sampling}

For each species two wood cores per tree were collected exclusively from the ranch in 2002 from ten trees, using an increment borer. Up to seven stem disks were collected for each species from fallen trees of known felling age from the ranch, adjacent community grazing and cultivated lands as well. However, the growth bands were extremely difficult to detect in the increment cores, in most cases, due to wedging rings and/or the presence of dark heartwood. About $60 \%$ of the stem disks collected from communal grazing lands and agricultural lands were not cross-datable as well. This was due to possible missing rings caused by human disturbances. Thus, the increment cores of all the species and the problematic stem disks were excluded. Instead, additional stem disks were collected exclusively from the ranch in 2003. The number of stem disks investigated, for each species, are indicated in Table 1.

Tree-ring analysis

Standard dendrochronological methods were used to prepare the samples for measurement. The surfaces of the stem disks were sanded gradually using sand paper of grit

Table 1 List of studied species with summary of their habit and annual growth increment

\begin{tabular}{|c|c|c|c|c|c|c|c|}
\hline \multirow[t]{2}{*}{ Species } & \multirow[t]{2}{*}{ Habit } & \multirow[t]{2}{*}{$N$} & \multirow{2}{*}{$\begin{array}{l}\text { Range in ages and } \\
\text { time span }\end{array}$} & \multirow[t]{2}{*}{ dbh $(\mathrm{cm})$} & \multicolumn{3}{|c|}{ Annual radial growth $(\mathrm{mm})$} \\
\hline & & & & & Mean & Maximum & Minimum \\
\hline A. senegal & $\begin{array}{l}\text { Deciduous shrub/tree, } \\
\text { up to } 10-15 \mathrm{~m}\end{array}$ & $8(6)$ & 28-69 (1937-2003) & $12.4-34.3$ & $2.53 \pm 0.35$ (a) & $9.12 \pm 0.92$ (a) & $0.30 \pm 0.15$ (a) \\
\hline A. seyal & $\begin{array}{l}\text { Deciduous tree } \\
\text { up to } 9 \mathrm{~m}\end{array}$ & $7(6)$ & 25-67 (1939-2003) & $15.8-27.7$ & $2.32 \pm 0.66$ (a) & $7.89 \pm 1.85$ (a) & $0.27 \pm 0.13$ (a) \\
\hline A. tortilis & $\begin{array}{l}\text { Deciduous tree, } \\
\quad 4-21 \mathrm{~m}\end{array}$ & $9(8)$ & 35-93 (1927-2003) & $12.2-34.8$ & $1.81 \pm 0.46$ (a) & $5.25 \pm 1.64(\mathrm{~b})$ & $0.34 \pm 0.29$ (a) \\
\hline B. aegyptiaca & $\begin{array}{l}\text { Evergreen small } \\
\text { tree up to } 8 \mathrm{~m}\end{array}$ & $6(4)$ & 50-70 (1936-2003) & $19.4-27.2$ & $1.93 \pm 0.30$ (a) & $4.58 \pm 0.74(b)$ & $0.40 \pm 0.14$ (a) \\
\hline
\end{tabular}

$N=$ number of stem disks investigated with successfully cross-dated trees in parenthesis (Note: from the successfully cross-dated trees, for $A$. senegal (2), A. seyal (1), A. tortilis (3) trees are from the community areas, while for B. aegyptiaca (4) of them are from the ranch); age range in years and time span in parenthesis; diameter range of the stem disk (dbh); annual radial increment (mean, maximum and minimum) with standard deviations calculated from tree ring measurements (number of trees used in parenthesis). Within a column, means followed by different letters were statistically different at $P<0.05$ 
size 80-600. To improve visibility of the growth zone boundaries, the wood dust was removed with compressed air. Tree-ring width was measured to the nearest $0.01 \mathrm{~mm}$ with a semi-automatic device (LINTAB, Rinn tech, Heidelberg, Germany), which consists of a stereomicroscope and a moveable board linked to a distance measuring device and a personal computer. To produce mean curves for each sample, ring width curves of individuals, from 2 to 4 radii, were cross-dated visually using pointer years (extreme wide or narrow rings). The pointer years allowed possible errors due to missing rings or false rings to be corrected (checked), hence the conditional dates were shifted in some cases to obtain a maximal similarity (match) between different curves. Furthermore the similarity of individual curves were tested statistically with the computer program Time Series Analysis and Presentation (TSAP) (Rinn and Jäkel 1997), which allowed: (a) the measurement of "Gleichläufigkeitskoeffizient" (GLK): the percentage year-to-year harmony in the fluctuation of two curves within the overlapping period (Schweingruber 1988); (b) the calculation of student's $T$-values that convey the degree of similarity of two curves (Baillie and Pilcher 1973); these statistics ( $a$ and b) were used in selecting the best correlated series to include for building mean chronologies; and (c) indexing: the removal of individual and long-term growth trends from the mean curves by division of a running mean of 5 years (Baillie and Pilcher 1973; Schweingruber 1988), which is indispensable to obtain an interpretable correlation coefficient with climate data (Cook and Briffa 1990).

Using the same method, successfully cross-dated mean ring width series of different sample trees were averaged to build species-specific mean chronologies. A master site chronology, with a length of 68 years, was further constructed by building the mean of the four species. In constructing species mean chronologies, the juvenile part of the wood (3-6 years) was excluded for two reasons. As mentioned by Worbes (2002) and others, it is the experience of most dendrochronological studies that compared to the mature part of the wood, juvenile wood reacts differently to drought physiologically due to competition. Moreover, browsing effects at seedling and sapling stages could be significant in the present study area, which may mask climate related signals in the tree rings.

Growth analysis

Tree-ring measurements were carried out on the longest radii. To minimize over or under- estimation of tree diameter annual radial increments were corrected by multiplying their values with the correction factor using the following formula:
Correction factor $=($ Provisional diameter $/$ actual diameter $)$ $\times 100$,

where provisional and actual diameters were measured from tree rings and a measuring tape, respectively.

\section{Climate data}

Precipitation and temperature data recorded since 1980 were obtained from a weather station at Adamitulu. Since the period covered by this station and others close to the study area was too short to gain reliable climate-growth related information, precipitation data during the period of 1930-1980 were obtained from the National Center for Atmospheric Research (http://ncardata.ucar.edu/datasets) for Region 27 as defined by Nicholson (2001). Nicholson (2001) regionalized the African continent according to climatic homogeneity with respect to the inter-annual variability of rainfall. Each region contains enough overlapping years to generate a long-term record. Therefore, mean monthly precipitation data from six identical climate areas (Region 27) for the period of 1930-1980 were calculated to obtain composite long-term mean monthly and annual precipitation series.

Data analyses

To evaluate and determine climate-growth relationships, the indexed mean ring width curves of each species and the master chronology were compared with indexed values of precipitation data from Adamitulu (22 years) (hereafter referred to as Adamitulu precipitation), and the long time series (66-73 years) derived from Nicholson (2001) (hereafter referred to as NCAR precipitation). We used correlation coefficients obtained between the treering index and Adamitulu precipitation values for the purpose of species comparisons, since the Adamitulu precipitation data were collected close to the study site. Indexed values of annual and major rainfall period (JuneSeptember) precipitation were separately checked for correlations with indexed ring width mean curves. Single spectrum analysis of the master chronology was also carried out to examine periodic events in time series (Jenkins and Watts 1968). Radial growth comparisons among the species were determined using one-way analysis of variance (ANOVA). When significant variations in the ANOVA were revealed, means were ranked using Tukey's test (Fowler et al. 1998). STATISTICA for Windows (Version 6.0) was used for the data analysis. Unless stated otherwise, results are statistically significant at $P<0.05$. 


\section{Results}

Tree-ring formation

All studied tree species form distinct tree-ring boundaries. The growth ring boundary of the acacias are characterized by thin parenchyma bands, which run around the entire stem disc (Fig. 2a-c). A thin parenchyma band and the accumulation of vessels characterize tree-rings of B. aegyptiaca. Additionally, when the rings are crossed with rays, the rays appear broader (Fig. 2d). The distinctiveness of the growth rings vary among the species. Among the deciduous species, A. seyal shows less distinct growth rings than $A$. senegal and A. tortilis. In A. seyal the vessels often mask the finer marginal band, which makes identifying the growth zones complicated. The growth rings of $B$. aegyptiaca are the least distinct. All the species show wedging rings, though the wedging rings are more apparent on B. aegyptiaca.

\section{Radial growth}

The width of rings varied considerably between years and among the species (in average maximum ring widths). Mean ring width differed regardless of their age class. Individual ring width of $A$. senegal and A. seyal range from 0.27 to $9.12 \mathrm{~mm}$ with overall means of $2.53 \pm 0.35$ and $2.32 \pm 0.66 \mathrm{~mm}$, respectively. A. tortilis and B. aegyptiaca showed significantly narrower ring width ranging from 0.34 to $5.25 \mathrm{~mm}$ with overall means of $1.81 \pm 0.46$ and $1.93 \pm 0.30 \mathrm{~mm}$, respectively (Table 1 ).
Cross-dating

Cross-dating between radii of the same disks and of different trees was successful in most cases. However, some stem disks collected from communal grazing lands and agricultural lands were not cross-datable. Cross-dating was successful for six out of eight trees for A. senegal and six out of seven trees for $A$. seyal, ranging in length between 25 and 69 years (Table 1). For A. tortilis, eight out of nine trees, ranging in length between 35 and 93 years, were cross-datable. The mean chronology for A. tortilis was constructed with a length of 73 years since the longest (93 years) was contributed only from one tree. B. aegyptiaca had the lowest number of cross-datable individual disks, i.e., four out of six trees (Table 1). Cross-dating of the four different species was successful for 22 out of 30 trees with a mean (GLK \%) range of $61-75 \%$.

Species response to precipitation

The individual (species) mean ring width curves showed annual patterns similar to seasonal precipitation. The high similarities are evident in the graphs between indexed major rainfall season precipitation data and mean ring width series (Fig. 3). In general, all the species showed high GLK $\%$ and $T$-values with both annual and major rainfall season precipitation (June-September) and notably with Adamitulu precipitation. Further, simple regression analyses indicated significant positive relationships between annual radial increments and both annual and
Fig. 2 Cross-sections of a $A$. senegal; b A. seyal; c A. tortilis; and $\mathbf{d} B$. aegyptiaca. The arrows indicate annual growth boundaries
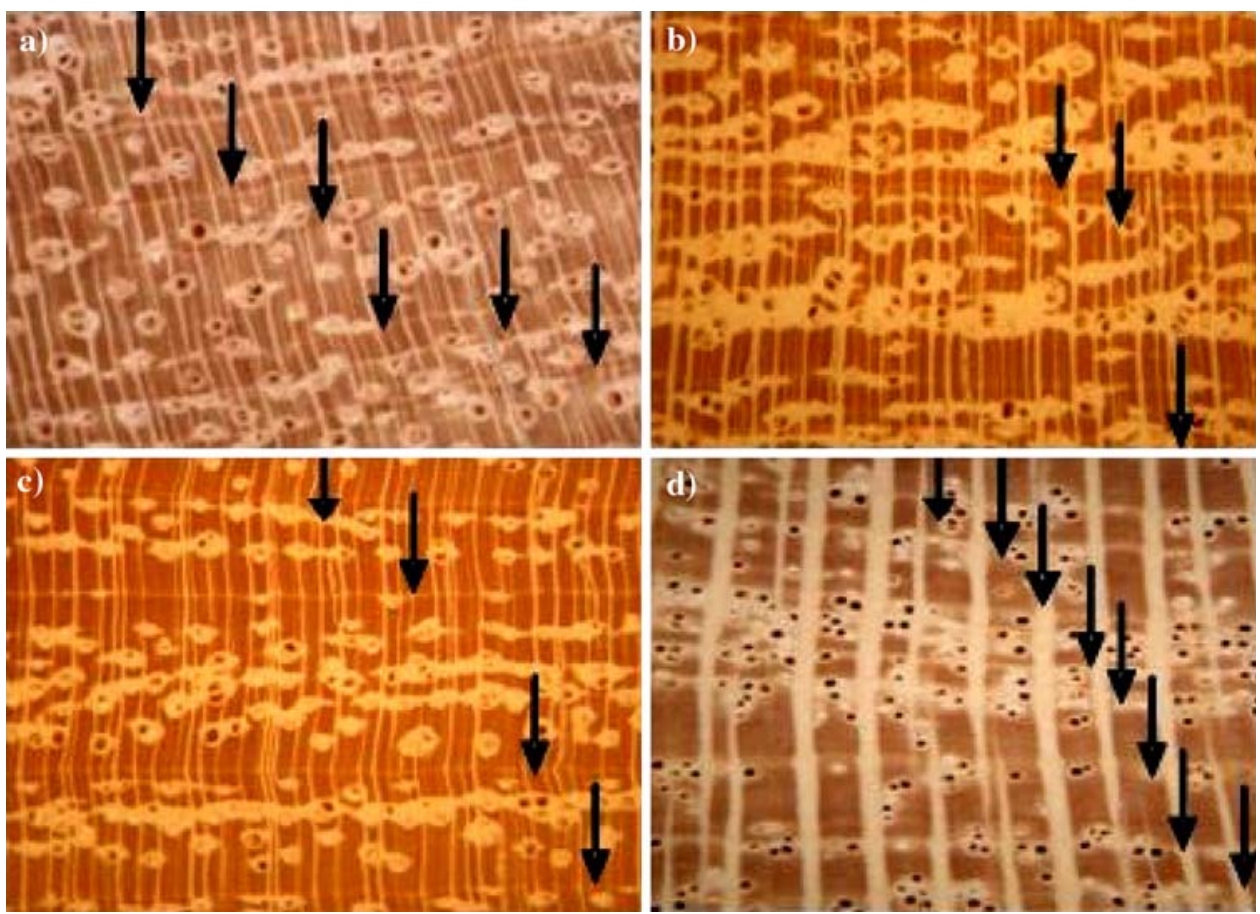

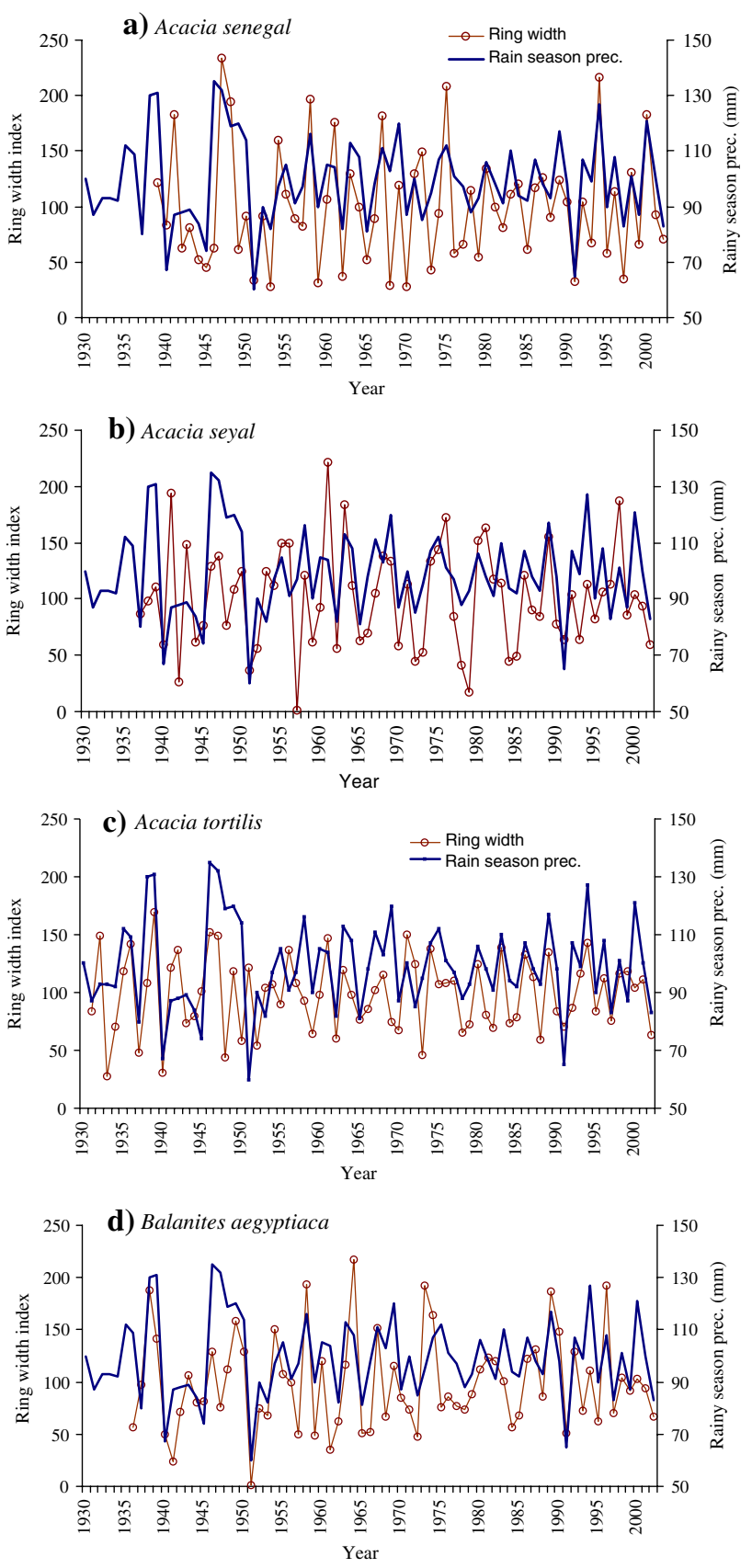

Fig. 3 Ring width indices of a A. seyal; b A. senegal; c A. tortilis; d $B$. aegyptiaca and major rainy season precipitation (June-September)

major rainfall season precipitations for all the species. For the deciduous species, except $A$. senegal, annual radial growth correlated more strongly with major rainfall season than annual precipitation recorded at Adamitulu. Of all the species, A. seyal appeared most sensitive to major rainfall season fluctuations with the highest correlation coefficient $(r=0.77)$, while $B$. aegyptiaca revealed the highest correlation $(r=0.66)$ with annual precipitation (Table 2).
Site master chronology, tree-ring pointer years, drought periods and ENSO events

The master chronology showed strong similarity to major rainy season precipitation (Fig. 4). The percentage of parallel run (GLK\%) and $T$-values between the master chronology, and both annual and major rainy season precipitation were higher than mean curves of the individual species. The master chronology also showed strong positive significant correlation with major rainy season and annual precipitation, particularly with Adamitulu precipitation (Table 3).

A close look at the master ring width curve (Fig. 4) indicated that tree-ring width was depressed from 1942 to 1945. In contrast to the decline in tree-ring width in the extreme drought years, the ring width increased concurrent with the wet years, notably from 1946 to 1950 . There were distinct pointer years with narrow rings in 1951/1952, 1955-1957, 1962 and 1965/1966. Despite some recovery in 1971, 1975 and 1980/1981, there was a slowdown in growth from 1970 to 1985 with sharp declines in 1970, 1972/1973, 1977-1979 and 1984/1985, whereas frequent narrow rings appeared every 2-3 years in the 1990s with sharp decline in 1991. When strong declines in tree-ring width were compared with past ENSO events and drought/ famine years in Ethiopia, they show a remarkable correlation (Table 4; Fig. 4). Single spectrum analysis of the master chronology also revealed periodically recurring events. The peaks for the year 1937-2002 were in the frequency areas of $0.14,0.22,0.35$ and 0.45 equivalent to periods of 7.1, 4.6, 2.7 and 2.2 years, respectively. The peaks in the frequency areas of $0.14,0.35$ and 0.45 are significant $(P<0.05)$ (Fig. 5).

\section{Discussion}

When plant water potential reaches its permanent wilting point during the dry season, drought deciduous species shed their leaves (Mitlöhner 1997; Gebrekirstos et al. 2006), and evergreen and deciduous species enter a period of cambial dormancy, which implies formation of growth boundaries (Worbes 1999). In agreement with this reasoning, both the evergreen and deciduous species showed distinct growth rings. Our results also agree with previous studies, which showed that acacias form distinct annual growth rings characterized by marginal parenchyma bands (Eshete and Ståhl 1999; Gourlay 1995, Gammadid 1989). The growth zones of $B$. aegyptiaca were separated by the accumulation of vessels associated with very thin parenchyma bands at the limits of growth zones.

Though all species showed the formation of growth rings, rings in deciduous acacias were more distinct than 
Table 2 Summary of Gleichläufigkeitskoeffizient (GLK\%), T-value (TV), Overlap period in years (OVL) and correlation coefficients ( $r$ ) between tree ring width indices and annual and major rainy season precipitation $(\mathrm{mm})$

\begin{tabular}{|c|c|c|c|c|c|c|c|c|c|c|c|c|c|c|c|c|}
\hline \multirow[t]{2}{*}{ Precipitation periods } & \multicolumn{4}{|c|}{ Acacia senegal } & \multicolumn{4}{|c|}{ Acacia seyal } & \multicolumn{4}{|c|}{ Acacia tortilis } & \multicolumn{4}{|c|}{ Balanites aegyptiaca } \\
\hline & OVL & GLK & TV & $r$ & OVL & GLK & TV & $r$ & OVL & GLK & TV & $r$ & OVL & GLK & TV & $r$ \\
\hline Annual $^{\mathrm{a}}$ & 67 & 72 & 4.5 & 0.43 & 64 & 73 & 3.2 & 0.46 & 73 & 68 & 4.0 & 0.42 & 67 & 65 & 6.1 & 0.53 \\
\hline Rain $^{a}$ & 67 & 73 & 4.4 & 0.43 & 64 & 74 & 3.8 & 0.53 & 73 & 71 & 4.0 & 0.43 & 67 & 75 & 6.6 & 0.59 \\
\hline Annual $^{\mathrm{b}}$ & 22 & 82 & 4.8 & 0.56 & 22 & 78 & 3.0 & 0.42 & 22 & 72 & 4.6 & 0.53 & 22 & 92 & 4.5 & 0.66 \\
\hline Rain $^{\mathrm{b}}$ & 22 & 85 & 3.7 & 0.46 & 22 & 85 & 4.4 & 0.77 & 22 & 80 & 4.2 & 0.64 & 22 & 90 & 3.6 & 0.60 \\
\hline
\end{tabular}

${ }^{a}$ NCAR precipitation

b Adamitulu precipitation

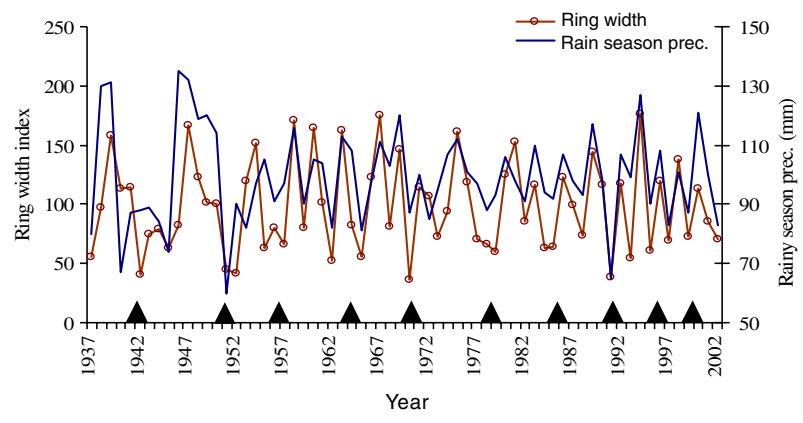

Fig. 4 Master ring width indices of the four species and major rainy season precipitation (June-September). Arrows indicate pointer years (extreme narrow rings)

Table 3 Summary of Gleichläufigkeitskoeffizient (GLK \%), $T$-value (TV), overlap period in years (OVL) and correlation coefficients $(r)$ between master ring width indices and annual and major rainy season precipitation $(\mathrm{mm})$

\begin{tabular}{lllll}
\hline Precipitation periods & \multicolumn{4}{l}{ Master chronology } \\
\cline { 2 - 5 } & OVL & GLK & TV & $r$ \\
\hline Annual $^{\mathrm{a}}$ & 67 & 80 & 6.2 & 0.59 \\
Rain $^{\mathrm{a}}$ & 67 & 76 & 6.1 & 0.61 \\
Annual $^{\mathrm{b}}$ & 22 & 92 & 5.5 & 0.64 \\
Rain $^{\mathrm{b}}$ & 22 & 98 & 6.0 & 0.79 \\
\hline
\end{tabular}

${ }^{a}$ NCAR precipitation

b Adamitulu precipitation

the evergreen $B$. aegyptiaca. A tendency for distinct ring formation by deciduous species compared to evergreen species was reported by (Worbes 1999), and distinctiveness was related to wood structure differences, which is genetically controlled (Detienne 1989; Worbes 1995). In addition to its wood structure, the frequent occurrences of wedging rings in $B$. aegyptiaca made the determination of growth boundaries more difficult. Wedging rings are believed to result from competition of species growing under poor light conditions (Worbes 2002). Since our study was conducted in open savanna woodlands, competition for light was unlikely. Nevertheless, competition for water resources is certain, which could cause uneven distribution of resources to initiate growth around the full circumference. Fire could have contributed to the formation of wedging rings as well. However, we did not observe fire scars in the stem disks investigated. Hence the formation of wedging rings could be attributed to genetic prerequisite (Lamarche et al. 1982) or to reduced water resources. The analyses of stem disks enhanced the detection of such ring irregularity by tracking the ring boundaries around the entire cross-section (Worbes 1995; Eshete and Ståhl 1999).

Cross-dating of the ring widths was mostly successful except for some stem discs collected from communal grazing and cultivated lands. This was due to possible missing rings. It is a common practice in the study area to prune (pollard) tree branches growing in cultivated lands to minimize competition with agricultural crops during the major rainy season and to cut branches for fuel wood and fodder from communal grazing lands. Since the photosynthetically active part of the tree would be removed by pollarding, it obviously would disrupt the normal growth of the trees. It is worth noting that the communal areas were part of the ranch until 1994, so the few trees successfully cross-dated from the communal areas (Table 1) were possibly not affected by human disturbances. Hence, our findings agree with Schweingruber (1996) that only trees from sites in undisturbed forests provide information useful for dendroclimatology.

The tree-ring chronologies presented (Fig. 2) are the first for B. aegyptiaca and the longest chronology, so far, for the acacias in Ethiopia. The coherent pattern of treering series among the chronologies of four species suggest that an external factor, precipitation, affected the species in a similar way (Table 2). Therefore the high positive correlations found between the chronologies and the precipitation variables may substantiate the formation of one tree-ring per year (annual nature of the growth rings). This is in agreement with the findings of Eshete and Ståhl 
Table 4 Tree ring pointer years compared with chronology of ENSO events and drought in Ethiopia
Extreme narrow rings of the master chronology (Fig. 4) and A. tortilis for the year 19301937 (Fig. 3) were selected as pointer years. The ENSO years drought/famine and their respective regions are from literature review (Degefu 1987; Wolde-Georgis 1997; Trenberth 1997)

\begin{tabular}{llll}
\hline Pointer years & El Niño years & Drought/famine & Regions \\
\hline $1933-1934$ & $1930-1932$ & $1932-1934$ & Ethiopia \\
$1942-1945$ & $1939-1942$ & Not reported & \\
$1951-1953$ & $1951-1952 / 1953-54$ & 1953 & Tigray and Wollo \\
$1955-1957$ & $1957-1958$ & $1957-1958$ & Tigray and Wollo \\
1962 & 1963 & Not reported & \\
1965 & $1965 / 1966$ & $1964-1966$ & Tigray and Wollo \\
1970 & $1969-1970$ & 1969 & \\
$1972-1973$ & $1972-1973$ & $1973-1974$ & Tigray and Wollo \\
$1977-1979$ & $1976-1977$ & $1978-1979$ & \\
$1984-1985$ & $1982-1983$ & $1984-1985$ & Ethiopia \\
1988 & $1986-1987$ & $1987-1988$ & Ethiopia \\
1991 & $1991-1992$ & $1991-1992$ & Ethiopia \\
1993 & 1993 & $1993-1994$ & Tigray, Wollo, Addis \\
1995 & $1994-1995$ & Not reported & \\
1997 & $1997-1998$ & $1997-1998$ & Ethiopia \\
1999 & & Not reported & \\
2002 & & 2002 & Ethiopia \\
\hline
\end{tabular}

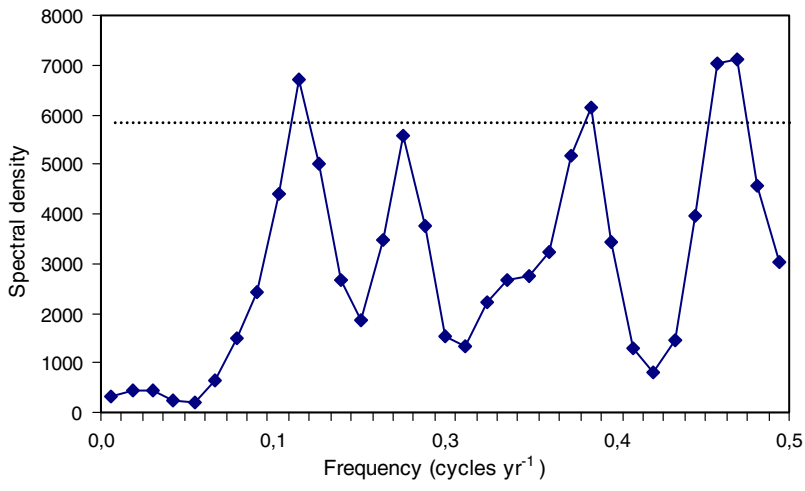

Fig. 5 Single spectrum analysis of the master ring width chronology. Frequencies at which the density peaks exceed the value of the dotted horizontal line are significant $(P<0.05)$

(1999) who reported that the acacias growing in dry sites (close to our study sites) form one ring per year, which they verified by counting tree rings of known age. In similar studies in tropical trees, successful cross-dating of individual or different species (Worbes 1995; Stahle et al. 1999; Worbes et al. 2003, Fichtler et al. 2004) and positive correlations between tree-ring width chronologies and precipitation variables (Worbes 1999) were used as evidence of the annual nature of growth rings. In light of the above discussion the annual nature of the growth rings is thus established in our study area and species.

The annual diameter increment of $3.6-5.0 \mathrm{~mm}$ in this study is similar to the average diameter increment of $4.2 \mathrm{~mm}$ per year projected by Eshete and Ståhl (1999) in the locality of our study area, which originated under similar climatic conditions, and $3.9 \mathrm{~mm}$ reported by
Kiyiapi (1994) with similar climatic conditions in Kenya. However, it is much lower than the 12-14 mm for Acacia karroo reported by Gourlay and Barnes (1994), and 10$14 \mathrm{~mm}$ for A. tortilis grown under favorable conditions reported by Lamprey et al. (1980). A. senegal and A. seyal showed enhanced growth performances compared with $A$. tortilis and B. aegyptiaca, especially in maximum radial growth, which seems to be associated with moist years (Table 1). This reflects their reaction to water availability, and it would be interesting to elucidate their growth performance with regard to their water-use behaviours.

Water relation studies on these species during the dry season in 2003 revealed that both A. senegal and A. seyal are drought sensitive (drought avoiders) while A. tortilis and B. aegyptiaca are drought tolerant (Gebrekirstos et al. 2006). The avoidance mechanism and opportunistic use of water by A. senegal and A. seyal may partially explain their growth reduction during drought years and enhanced growth performances during moist years. A. tortilis and $B$. aegyptica are conservative water users, which is consistent with their lower growth performances in moist years compared to the former species. This finding is in agreement with similar results from the study of Orwig and Abrams (1997). During drought years, drought-sensitive species show reduced growth compared to drought tolerant species, while they show enhanced growth during moist years. Similarly, one would expect the deciduous, notably the drought-sensitive species to show better correlation with climate parameters, especially with major rainy season precipitation since they are expected to be leafless during the dry season. However, as shown in Table 2, annual radial growth of $A$. seyal and A. tortilis showed 
stronger correlation with major rainy season precipitation, while $A$. senegal and B. aegyptiaca strongly correlated with annual precipitation. In contrast to our results, however, Enquist and Leffler (2001) found the evergreen species (Capparis indica) and the deciduous (Genipa Americana) to be more sensitive to the peak (major) rain and minor rainfall amount, respectively. On the other hand, in agreement with our results, higher correlation of evergreen species with annual rainfall (Terminalia guianensis $r=0.68$ and Pinus caribaea $r=0.57$ ) was reported by Worbes (1999), which may indicate longer growth period activity.

The statistically significant correlation between master ring chronologies and precipitation data also provides us a high degree of confidence in the reliability of cross-dating (Table 3). Similar findings, stronger correlations of master ring chronologies than individual species curves, have been reported (e.g., Worbes 1999; Schöngart et al. 2006). Hence, it seems plausible to use the pointer years of these chronologies as an indicator of climate disturbance events. Pointer rings are conspicuously small or wide rings and show density fluctuations (Schweingruber et al. 1990), thereby enabling the cross-dating of different samples because they are formed in response to an extreme external event that affected all trees in the same way (Worbes 1995). Thus, the comparatively synchronised growth reductions shared by all species were probably the outcome of the frequent drought occurrences in Ethiopia.

A variety of historical records and proxy records provided a reference framework for assessing climatic extremes in Ethiopia, although few meteorological records can cover this period. Drought has affected millions of people in Ethiopia for a long time. The recent extreme severity of drought during 1973-1986 and its political and economic consequences were reported by different authors (Kiros 1991; Adhana 1991; Cutler 1991). Archives also demonstrate that lack of fodder during these extreme drought periods caused a heavy mortality of domestic livestock indicating the extensive influence of the severe persistent drought on woodlands and grasslands. This is evident by the high frequency of narrow rings and the incidence of large growth depressions in the 1970s and 1980 s in the tree-ring chronologies. This event is more obvious in the graph of B. aegyptiaca (Fig. 3d).

The ENSO effect and drought years in Ethiopia are associated with the occurrence of narrow rings, i.e., pointer years (Table 4; Fig. 4). However, consistent with the occurrence of drought years in relation to the El Niño years (Wolde-Georgis 1997) some pointer years coincided with ENSO years and some followed it. ENSO years are characterized by below normal rainfall. It reduces and interrupts the major rainfall season and enhances the minor rainfall season in Ethiopia. The relationship between ENSO and Ethiopian rainfall and atmospheric system are described elsewhere (Bekele 1993). In addition to the recognized drought years listed in Table 4, except for the year 1962, the existence of pointer years in 1940$1945,1951 / 52,1970,1977-1979$ were found to be associated with ENSO years adding to the presumption that trees are climatic event archives. The pointer year in 1962 could be due to local climatic effects. Although savanna trees are thought to be drought hardy, the lower growth increment in drought years relative to normal years revealed the impact of drought (ENSO) on the productivity of savanna woodlands.

Based on previous drought occurrences and the frequency of rainfall deviation from the average, Tesfaye (1988) reported periodic droughts every 3-5 and 6-8 years in northern Ethiopia and every 8-10 years in the whole country. This is similar to our findings of 7.1, 4.7 and 2.2-2.7 years of periodic drought events revealed by the tree rings. These peaks fall within a spectral peak equivalent to 2-8 years, which characterize the variability of ENSO-related time series (Rasmusson and Carpenter 1982; Schöngart et al. 2004, 2006). Similar to our results, correlations, mainly between tree-ring width, precipitation and ENSO in semi-arid Africa have been reported elsewhere (e.g. Fichtler 2004; Schöngart et al. 2004; Couralet et al. 2005).

There are two main outcomes of this study, which have important implications for paleoclimatic reconstructions and in restoration of degraded lands. Our results support the strong linkage between tree-ring chronologies and climate, and it appears feasible to use tree-ring width variations for climate reconstruction, a chronology of past drought and ENSO events. In addition, the growth dynamics of the species coincided with the drought tolerance characteristics of the species (Gebrekirstos et al. 2006). Hence, A. tortilis and B. aegyptiaca can be considered as suitable candidates for reforestation in droughtprone areas while the higher growth rates of $A$. senegal and A. seyal during moist years could make them suitable candidates in areas of less limiting water conditions. Our study sheds light on the potential of dendrochronological studies developing in Ethiopia. Further studies on longterm tree-ring chronologies are recommended to reconstruct climate fluctuations.

Acknowledgments The study was financed by the German Academic Exchange Service (DAAD), which is gratefully acknowledged. We thank Wondo Genet College of Forestry, Hawassa University for logistic support. We extend our thank to the staff members of Abernosa Ranch for their kind assistance and logistic support during the fieldwork. We are grateful to Dr. A. Verheyden and Ester Fichtler for their valuable comments during preparation of the manuscript. We are grateful to the three anonymous reviewers for their constructive comments, which helped us to improve the quality of the article. 
Open Access This article is distributed under the terms of the Creative Commons Attribution Noncommercial License which permits any noncommercial use, distribution, and reproduction in any medium, provided the original author(s) and source are credited.

\section{References}

Adhana AH (1991) Peasant response to famine in Ethiopia, 19751985. AMBIO 20(5):186-188

Argaw M, Teketay D, Olsson M (1999) Soil seed flora, germination and regeneration pattern of woody species in an Acacia woodland of the Rift Valley in Ethiopia. J Arid Environ 43:411-435

Azene Bekele T, Birne A, Tengnas B (1993) Useful trees and shrubs for Ethiopia: identification, propagation and management for agricultural and pastoral communities. Regional Soil Conservation Unit, RSCU/SIDA, Nairobi

Baillie MGL, Pilcher JR (1973) A simple cross dating program for tree-ring research. Tree-Ring Bull 33:7-14

Bekele F (1993) Ethiopian use of ENSO information in its seasonal forecasts. http://www.esig.ucar.edu/ijas/ijasno2/bekele.html

Cook ER (1992) Using tree rings to study past El Niño Southern Oscillation influences on climate. In: Diaz FH, Markgraf V (eds) El Niño: historical and paleoclimatic aspects of the southern oscillations. Cambridge University Press, New York, pp 203 214

Cook ER, Briffa K (1990) Data analysis. In: Cook ER, Kairiukstis LA (eds) Methods of dendrochronology. Applications in the environmental science. Kluwer Academic publishers, Dordrecht, pp $97-162$

Couralet C, Sass-Klaassen U, Sterck F, Bekele T, Zuidema PA (2005) Combining dendrochronology and matrix modelling in demographic studies: An evaluation for Juniperus procera in Ethiopia. Forest Ecol Manage 216:317-330

Cutler P (1991) The political economy of famine in Ethiopia and Sudan. AMBIO 20(5):176-178

Detienne P (1989) Appearance and periodicity of growth rings in some tropical woods. IAWA Bull 10:123-132

Degefu W (1987) Some aspects of meteorological drought in Ethiopia. In: Glantz MH (ed) Drought and hunger in Africa. Cambridge University Press, Cambridge

Eshete G, Ståhl E (1999) Tree rings as indicators of growth periodicity of acacias in the Rift Valley of Ethiopia. Forest Ecol Manage 116:107-117

Eshetu Z, February, E (2003) Dendroclimatology in the Western Cape, South Africa. In: Joint International Conference South African Association of Botanists and the International Society for Ethnopharmacology, Pretoria, pp 38

Enquist BJ, Leffler AJ (2001) Long-term tree-ring chronologies from sympatric tropical dry forest trees: individualistic response to climate variation. J Trop Ecol 17:41-60

FAO (1981) Forest resources of tropical Africa. FAO, Rome

Fichtler E, Trouet V, Beeckman H, Coppin P, Worbes M (2004) Climatic signals in tree rings of Burkea africana and Pterocarpus angolensis from semiarid forests in Namibia. Trees 18:442451

Fowler J, Cohen L, Jarvis P (1998) Practical statistics for field biology, 2nd edn. Wiley, New York

Gammadid ID (1989) Study of growth rates of Acacia bussei (Harms ex.) Sjostedt in the bay region of Somalia. Commonw For Rev 68:27-35

Gebrekirstos A (2006) Stable carbon isotopes and plant water relations in the Acacia savanna woodlands of Ethiopia: implications for reforestation and paleoclimatic reconstructions. $\mathrm{PhD}$ Thesis, Goettingen University, Cuvillier Verlag Goettingen, Germany

Gebrekirstos A, Demel T, Masresha F, Mitlöhner R (2006) Adaptation of five co-occurring tree and shrub species to water stress and its implication in restoration of degraded lands. For Ecol Manage 229:259-267

Gourlay ID (1995) Growth ring characteristics of some African Acacia species. J Trop Ecol 11:121-140

Gourlay ID, Barnes RD (1994) Seasonal growth zones in the wood of Acacia karroo Hayne: their definition and implications. Commonw For Rev 73:121-127

Hedberg I, Edwards S (1989) Flora of Ethiopia, vol 3. The National Herbarium, Addis Ababa University, Addis Ababa, Ethiopia and Department of Systematic Botany, Uppsala University, Uppsala, Sweden, $659 \mathrm{pp}$

Jacoby GC (1989) Overview of tree-ring analysis in tropical regions. IAWA Bull 10(2):99-108

Jenkins GM, Watts DG (1968) Spectral analysis and its applications. Holden-Day, San Francisco

Kiros F (1991) Economic consequences of drought, crop failure and famine in Ethiopia, 1973-1986. AMBIO 20(5):183-185

Kiyiapi JL (1994) Structure and characteristics of Acacia tortilis woodland on the Njemps flats. Adv GeoEcol 27:47-69

LaMarche JVC, Cook ER, Baillie MGL (1982) Sampling strategies. In: Hughes MK, Kelly PM, Pilcher JR, LaMarche JVC (eds) Climate from tree rings, Cambridge University Press, Cambridge, pp 2-7

Lamprey HF, Herlocker DJ, Field CR (1980) Report on the state of knowledge on browse in East Africa. In: Le Houerou HN (ed) Browse in Africa. ILCA, Addis Ababa, pp 33-54

Lang GE, Knight DH (1983) Tree growth, mortality, recruitment, and canopy gap formation during a 10-year period in a tropical moist forest. Ecology 64:1075-1080

Lemeneh M, Abebe T, Olsson M (2004) Gum and resin resources from some Acacia, Boswellia and Commiphora species and their economic contributions in Liban, Southeast Ethiopia. J Arid Environ 56:149-166

Lieberman M, Lieberman R, Peralta R, Harstshorn GS (1985) Mortality patterns and stand turnover rates in a wet tropical forest in Costa Rica. J Ecol 73:915-924

Makin MJ, Kingham JJ, Waddams AE, Birchall CJ, Tamene T (1975) Development prospects in the southern Rift Valley, Ethiopia. Land Resource Division, Ministry of Overseas Development, England KTB 7DY, V.II

Mitlöhner R (1997) Using trees as indicators of environmental conditions by measuring their internal water status. Plant Res Dev 45:33-50

Nicholson SE (2001) A semi quantitative, regional precipitation data set for studying African climates of the nineteenth century. Part I. Overview of the data set. Clim Change 50:317-353

Orwig DA, Abrams MD (1997) Variation in radial growth responses to drought among species, site and canopy strata. Trees 11:474484

Pilcher JR (1990) Sample preparation, cross dating and measurement. In: Cook ER, Kairiukstis LA (eds) Method of dendrochronology application in the environmental science. Kluwer Academic publishers, Dordrecht, pp 40-51

Pumijumnong N (1999) Climate-growth relationships of teak Tectona grandis (L.) from northern Thailand. In: Veter RE, Wimmer R (eds) Tree ring analysis: biological, methodological and environmental aspects. CAB International, Wallingford, pp 155-168

Rasmusson EM, Carpenter TH (1982) Variations in tropical sea surface temperature and surface wind fields associated with the southern oscillation/El Niño. Monthly Weather Rev 110:354384 
Rinn F, Jäkel S (1997) TSAP, reference manual. TSAP, Heidelberg

Sass U, Eckstein D (1995) The variability of vessel size in beech (Fagus sylvatica L.) and its ecophysiological interpretations. Trees 9:247-252

Schöngart J, Junk WJ, Piedade MTF, Avres JM, Huttermann A, Worbes M (2004) Teleconnection between tree growth in the Amazonian flood plains and the El Niño-southern oscillation effect. Glob Chang Biol 10:1-10

Schöngart J, Orthmann B, Hennenberg KJ, Porembski S, Worbes M (2006) Climate-growth relationships of tropical tree species in West Africa and their potential for climate reconstruction. Glob Chang Biol 12:1139-1150

Schweingruber FH (1988) Tree rings: basics and applications of dendrochronology. Kluwer Academic publishers, Dordrecht, pp 276

Schweingruber FH (1996) Tree rings and environment. Dendroecology. Birmensdorf, Swiss Federal Institute for forest, snow and landscape research. Berne, Stuttgart, Vienna, Haupt. 609 pp

Schweingruber FH, Aellen-Rumo K, Weber U, Wehrli U (1990) Rhythmic growth fluctuations in forest trees of Central Europe and the Front Range in Colorado. Trees 4:99-106

Stahle DW, Mushove PT, Cleaveland MK, Roig F, Haynes GA (1999) Management implications of annual growth rings in Pterocarpus angolensis from Zimbabwe. For Ecol Manage 124:217-229

Tesfaye H (1988) Causes and characteristics of drought in Ethiopia. Ethiop J Agric Sci 10:85-97

Therrell MD, Stahle DW, Ries LP, Shugart HH (2006) Tree-ring reconstructed rainfall variability in Zimbabwe. Clim Dyn 26:677-685

Trenberth KE (1997) The definition of El Niño. Bull Am Meterol Soc 78:2771-2777
Vetter RE, Botosso PC (1989) Remarks on age and growth rate determination of Amazonian trees. IAWA Bull 10:133-145

Walter H (1973) Vegetation of the earth in relation to climate and ecophysiological conditions. Springer, New York, pp 237

Wayant JG, Reid RS (1992) Determining the age of Acacia tortilis with ring counts for South Turkana, Kenya: a preliminary assessment. Afr J Ecol 30:176-180

Whitmore TC (1998) An introduction to tropical rain forests. Oxford University Press, Oxford

Wils, THG, Eshetu Z (2007) Reconstructing the flow of the River Nile from Juniperus procera and Prunus Africana tree rings (Ethiopia) — an explorative study on cross-dating and climate signal. In: Tree rings in archaeology, climatology and ecology (TRACE), vol 5, Proceedings of Dendrosymposium 2006, pp 277-284

Wolde-Georgis T (1997) El Niño and drought early warning in Ethiopia. http://www.bradford.ac.uk/research/ijas/Ijasno2/Georgi

Worbes M, Klinge H, Revilla JD, Martius C (1992) On the dynamics, floristic subdivision and geographical distribution of varzea forests in central Amazonia. J Veg Sci 3:553-564

Worbes M (1995) How to measure growth dynamics in tropical trees-a review. IAWA J 16:337-351

Worbes M (1999) Annual growth rings, rainfall dependent growth and long-term growth patterns of tropical trees from the Forest Reserve Caparo in Venezuela. J Ecol 87:391-403

Worbes M (2002) One hundred years of tree ring research in the tropics-a brief history and an outlook to future challenges. Dendrochronologia 20:217-231

Worbes M, Staschel R, Roloff A, Junk WJ (2003) Tree ring analysis reveals age structure, dynamics and wood production of a natural forest stand in Cameroon. For Ecol Manage 173:105-123 